Indexed by

\title{
THE EFFECT OF TEMPERATURE ON SOME ENGINEERING AND CONSOLIDATION PROPERTIES OF SOFT SOIL
}

\section{Rusdiansyah}

Lambung Mangkurat University, Faculty of Engineering, Department of Civil Engineering, Banjarbaru, Indonesia

\section{Markawie}

Lambung Mangkurat University,

Faculty of Engineering, Department of Civil Engineering, Banjarbaru, Indonesia

Key words: temperature, characteristics of consolidation testing techniques, soil compressive behavior, soft clay

doi:10.5937/jaes0-29477

Cite article:

Rusdiansyah, Markawie. (2021), THE EFFECT OF TEMPERATURE ON SOME ENGINEERING AND CONSOLIDATION PROPERTIES OF SOFT SOIL, Journal of Applied Engineering Science, 19(3),

750-756, DOI:10.5937/jaes0-29477

Online aceess of full paper is available at: www.engineeringscience.rs/browse-issues 


\title{
THE EFFECT OF TEMPERATURE ON SOME ENGINEERING AND CONSOLIDATION PROPERTIES OF SOFT SOIL
}

\author{
Rusdiansyah*, Markawie \\ Lambung Mangkurat University, Faculty of Engineering, Department of Civil Engineering, Banjarbaru, \\ Indonesia
}

This article defines the effect of temperature on some engineering and consolidation properties of soft soil. The purpose of this research, therefore, was to determine the technical characteristics of soft clay consolidation behavior, specifically in terms of temperature influence on varying values of soil established mechanical parameters, including soft soil compression index (Cc), swelling index (Cs), volume change coefficient (mv), consolidation coefficient (Cv), and the permeability coefficient ( $k$ ). In this analysis, the use of soft clay in an undisturbed condition was sourced from a swampy location in South Kalimantan Province, Indonesia. Also, the temperatures applied to the specimens were $22^{\circ} \mathrm{C}, 40^{\circ} \mathrm{C}, 60^{\circ} \mathrm{C}$, and $70^{\circ} \mathrm{C}$. The results showed the influence of temperature modifications on soil compressibility, where extensive heat was responsible for abundant soil compressibility. In addition, the associated parameters, termed soil compression index value (Cc), consolidation coefficient (Cv), and the swelling index (Cs), observed an increase by 3\%, 33\%, and 22\%, respectively. Furthermore, existence of high temperatures limited the unstable soil volume, where the volume change coefficient $(m V)$ tends to decrease by $3 \%$. Also, varying temperatures essentially altered soil permeability, where the seepage properties of soft clay showed the tendency to increase by $32 \%$, with rising soil temperature.

Key words: temperature, characteristics of consolidation testing techniques, soil compressive behavior, soft clay

\section{INTRODUCTION}

The abundance of land mass in Kalimantan, Indonesia are predominantly swamps, with soil types ranging from soft clay to peat. Based on a geotechnical perspective, soft soil characteristics are primarily not suitable for construction. For instance, roads built under this condition showed a tendency for bearing capacity failure, large subsidence, and a relatively long settlement period, as well as low slope stability (easily landslides), without any soil improvement.

Soil consolidation simply refers to water discharge through the pores, due to applied force (load), subsequently leading to land subsidence. Based on existing classical consolidation theory, size and duration of land subsidence are strongly modified by the soil's physical and mechanical properties, as well as the amount of effective load. For example, Holtz [1] generally stated the softer soil conditions are proven to instigate an increase in size and duration. However, till date, the classical consolidation theory in clay has not considered the effects of temperature changes. Similarly, very few current researchers have not developed a comprehensive analysis of these effects on soil consolidation behavior, particularly for soft clay.

Furthermore, soft soils, including fibrous peat, occur abundantly in Kalimantan.

Apart from initiating problems of carrying capacity and land subsidence, these soils also appear very prone to violent land fire events, specifically during dry seasons. Moreover, the existence of peatland fires significantly in- creases soil temperature of road body heap and the clay mass (base soil), provided the peatlands are positioned at both sides of the road construction.

The increase in subgrade temperature due to heat propagation from land fires is believed to influence the physical and mechanical properties of soft clay. Based on the consolidation theory, the soil demonstrated properties detrimental to the proposed construction, in the form of relatively large subsidence and the duration, under load condition. However, by increasing temperature, the soil consolidation behavior becomes affected, and in turn, possibly influences the magnitude and subsidence duration.

The temperature increase in soil mass of road body areas, commonly occurs, due to heat transfer from surrounding peatland fires in South Kalimantan, Indonesia. In certain road segments, bumpy roads (subsidence non-uniform) are prevalent. A significant effect of high temperature on soil consolidation behavior is assumed to exist, including non-uniform subsidence.

The research on soil characteristics, due to temperature changes is relatively minimal, despite being a phenomenon circumstance. For instance, a temperature rise was observed below the surface. Apart from the problem of heat propagation under the road caused by land fires, the presence of nuclear waste heat facilities in the soil medium was also an influence [2]. The hotness beneath the surface, as a result of embedded gas and oil pipeline activities, produces surrounding heat [4], as well as the heat storage energy reservoirs resident in the soil [5].

This research was conducted to provide solutions to the behavior of soft clay consolidation curve, due to tem- 
perature changes, particularly to determine the effect of these heat variations on the value of soil consolidation mechanical parameters, including compaction index (Cc), development index (Cs), volume change coefficient (mv), consolidation coefficient ( $\mathrm{Cv}$ ), and the permeability coefficient $(\mathrm{k})$.

Also, the paper is aimed at developing the results from selected previous investigations encumbered with certain limitations.

A study on the effects of temperature on Kaolinite clay characteristics at $5^{\circ} \mathrm{C}, 15^{\circ} \mathrm{C}$, and $40^{\circ} \mathrm{C}$., have been reported by Mon's et al [6], prominent researchers from Japan and Denmark. The results showed an increase in temperature also triggered higher compression index (Cc) and consolidation coefficient (Cv). However, the scope obtained by Mon's et al [6] varied from previous researches, with certain limitations in terms of selected clay type in the form of pure kaolinite, and is not classified as soft clay from natural processes, in addition to dominant environmental influence. Moreover, Mon's et al. [6] did not comprehensively discuss the heat effects on the soil consolidation behavior.

Several studies have been conducted related to temperature effects on clay properties, but also experienced certain challenges on the parameters and soil types. These attempts involved Burghignoli et al. [7], Baldi et al. [8], Romero et al. [9], Sridharan et al. [10], Gadzama et al. [11], Laloui [12], Tsutsumi et al. [13], and Towhata et al [14].

Research by Burghignoli's et al. [7] applied clay with excess silt content, and minor sand proportion. The results observed a change in pore quantity during the composting process of soil particles, where temperature change was instigated by the stress and heat histories, and the time interval between the end of the primary consolidation phase and commencement of the heating process.

Baldi's et al. [8] showed intense temperature causes the water volume in soil pores to vary, after examining changes in water volume and mineral systems in clay with low porosity. In addition, temperature is also known to affect the strain of soil volume, and the distance from the surface of soil minerals. Furthermore, the effects of heat on over consolidated Bangkok clay was investigated by Naga's et al [15], where the results revealed higher temperatures probably decline pre-consolidation stress.

Romero's et al [9] have also experimented on the effects of temperature on hydraulic behavior of unsaturated clay. The results showed a temperature surge possess the capability to reduce water content and total suction, as well as alter the clay structure and pore water flow.

The mechanism of changes in saturated soil volume and the concept of effective stress due to temperature influence have been investigated by Sridharan's et al [10]. The results showed extreme temperatures significantly modified the physical forces between soil particles, resulting in changes to pore water flow capacity, water escapes, and water concentration in soil pores.
Several studies have been generated by Gadzama's et al [11], including changes in the Atterberg limit values, due to temperature influence. The results indicated the LL liquid limit value decreased with an expansion in soil temperatures. This condition was caused by the physical and chemical reactions as the heat is added, and subsequently led to the disintegration of bonds in soil particles. Laloui [12] has studied the thermally induced effects on soil, using a suitable constitutive model for numerical simulations. The results revealed the existence of stress contraction phase at rising temperatures.

The effects of combined strain velocity and temperature on the consolidation behavior of clay soils has been investigated by Tsutsumi et al. [13]. Specifically, the relationship between stress and strain of clay soils during temperature changes was comprehensively analyzed. The results indicated the effective stress of collapse decreased with increasing temperature to form a new soil structure.

Towhata's et al [14] research was based on the volume change behavior of common and excessive consolidated clay kaolinite and bentonite, due to temperature alterations. The results showed a lesser shrinkage volume change, compared to ordinary consolidated clay at applied heat. Furthermore, an increase in soil permeability due to high temperature, causes the viscosity of soil fluids to decline.

\section{MATERIALS AND METHODS}

\section{Material}

Lom with high stability in undisturbed conditions sourced from swamps in South Kalimantan province, Indonesia, was employed in the consolidation test in determining soil congestion behavior. Table 1 represents the physical and mechanical characteristics of soft clay applied as the test object.

Table 1 also shows the selected clay types were classified as soft clay comprising minimal organic matter with

Table 1: Characteristics of clay used

\begin{tabular}{|c|c|}
\hline Properties & Characteristic Value \\
\hline - $\quad$ Volumetric Weight, $\gamma\left(\mathrm{kN} / \mathrm{m}^{3}\right)$ & 15.22 \\
\hline - Water Content, Wn (\%) & $56-70$ \\
\hline - $\quad$ Organic content, Oc (\%) & $5-8$ \\
\hline - $\quad$ Spesific Gravity, Gs & 2.63 \\
\hline - $\quad$ Cohesi, C $\left(\mathrm{kN} / \mathrm{m}^{2}\right)$ & $10-15$ \\
\hline - $\quad$ qc CPT, $\left(\mathrm{kN} / \mathrm{m}^{2}\right)$ & $7.5-12$ \\
\hline - Initial void ratio, eo & 1.25 \\
\hline - $\quad$ Liquid limit, LL (\%) & 60 \\
\hline - $\quad$ Plastic Index, PI (\%) & 22 \\
\hline - $\quad$ Liquidity Index, LI & 0.85 \\
\hline - $\quad$ Activity, A & 0.46 \\
\hline - Sensitivity, St & 1.56 \\
\hline - USCS Classification & $\mathrm{OH}-\mathrm{MH}$ \\
\hline
\end{tabular}




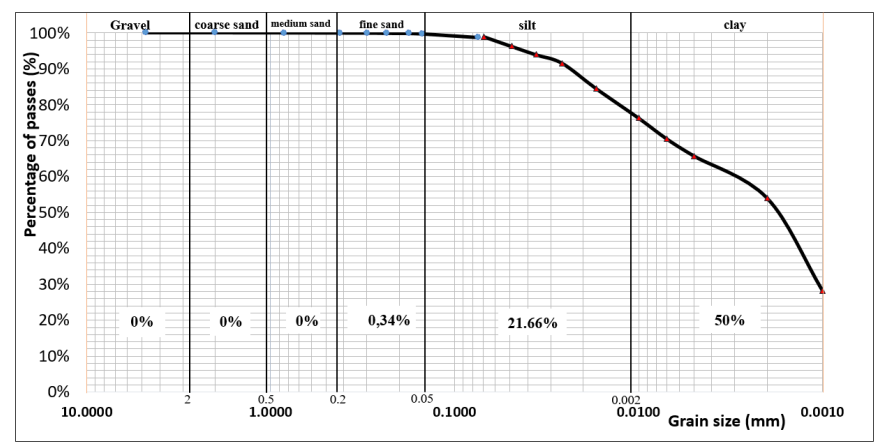

Figure 1: Grain size distribution chart

the $\mathrm{OH}-\mathrm{MH}$ classification (USCS method). Based on shear strength (cohesion), the soil sample was classified as clay, with very tender properties. This statement was supported by the results of grain size distribution test in Figure 1, where the percentage of silt and clay soils was above $50 \%$ and were also classified as fine-grained soil (USC method).

\section{Testing procedure}

Figure 2 shows a modified consolidation test instrument (Odoemeter). These alterations refer to the research results by Naga's et al [15]. The process was performed within the consolidation cell (outer ring odoemeter) by installing an electric heater, pre-connected to the temperature controller with an accuracy of $+/-0.1^{\circ} \mathrm{C}$. Furthermore, the controller was also attached to a thermo sensor device to read the amount of water temperature in the consolidation cell needed to match the desired thermometer value.

Subsequently, the temperature control was set in the range of $20-100^{\circ} \mathrm{C}$, while the individual temperature was varied at $40^{\circ} \mathrm{C}, 60^{\circ} \mathrm{C}, 75^{\circ} \mathrm{C}$, and $85^{\circ} \mathrm{C}$. The temperature was assumed to reduce, due to the heat propagation process causing increased temperature of soft clay above normal condition. Based on research implementation, the temperature range values referred to the results of Donna's research regarding the amount of temperature occurring above $39^{\circ} \mathrm{C}$, attributed to the burning of plants/ plant fibers.

The consolidation test stage involved a higher temperature, prior to load application and reading of the decreasing values from the dial gauge. However, a time lag of approximately 7 minutes was provided, as the heat increased in the consolidation cell. This interval tends to generate temperature homogeneity in soil specimens in the consolidation ring with the water temperature at the outer cell.

Furthermore, the test results with the desired hotness at the final stage were parameters, termed compression index $(\mathrm{Cc})$, consolidation coefficient (Cv), swelling index (Cs), volume change coefficient (mv), and permeability coefficient (k).
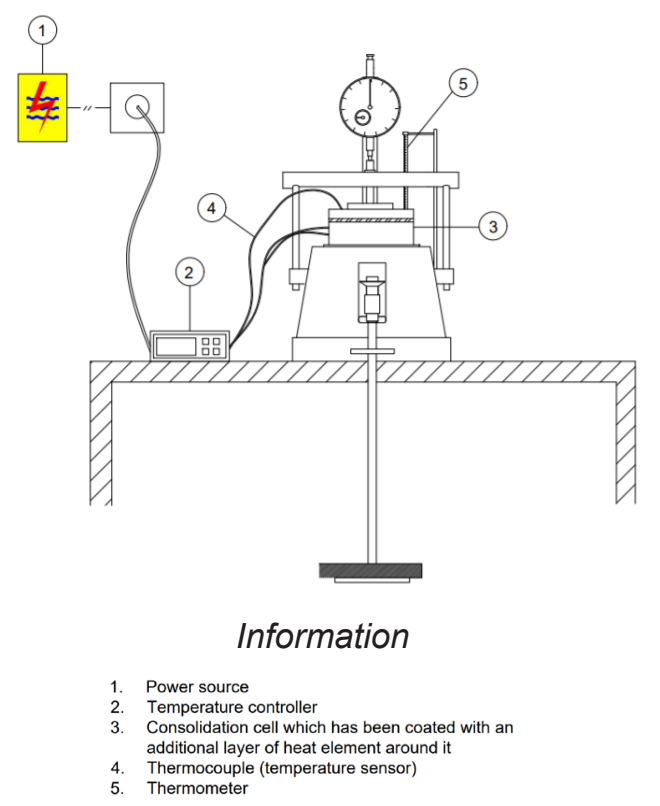

(a)

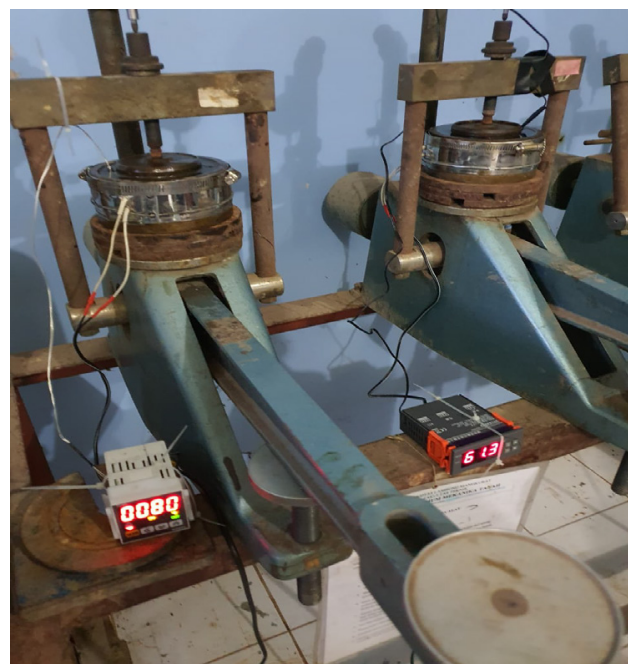

(b)

Figure 2: Modified consolidation test equipment

(a) Tool scheme

(b) Visual consolidation modification tool

\section{RESULTS AND DISCUSSION}

\section{Relation of compression index (Cc) and temperature $\left(T^{\circ} \mathrm{C}\right)$}

Figure 3 highlights the temperature $(T)$ influence on compression index $(\mathrm{Cc})$ of the soft clay. The results showed the temperature affects the soil compressibility behavior through changes in the value of the soil compressive index (Cc). Based on Figure 3, intense temperature ( $\mathrm{T}$ ) tends to improve the soil compression index (Cc) by an average of $3 \%$. This condition occurred as a result of changes in the amount of soil void ratio (e) after applying heat.

Figure 4 shows the change in pore quantity (e/eo) due to extreme heat and also displays the comparison at normal and maximum temperature conditions. Also, an 


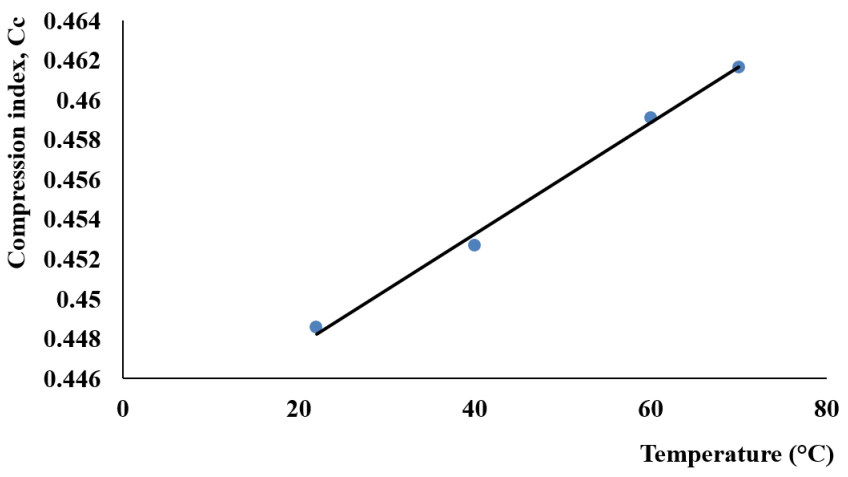

Figure 3: Relationship of compression index (Cc) and temperature variation

increase in applied heat on soft clay tend to enhance this amount, particularly above a stress of $0.5 \mathrm{~kg} / \mathrm{cm}^{2}$. Meanwhile, hot conditions generated $10 \%$ pore improvement, compared to normal state.

Furthermore, the variation in void ratio (e) causes alterations in pore water behavior. Burghignoli's et al [7] stated the deformation process occurred as a result of the dissipation of excess pore water pressure from temperature changes. Baldi's et al [8] have also reported the increase in applied heat instigated varying water volume in the soil pore. The results of Goodman et al research's [17] show minimal changes in soil fabric with increased temperature.

Therefore, extreme temperatures are known to trigger change in the volume of the clay to expand on receiving heat. Furthermore $\mathrm{Ng}, \mathrm{C} . \mathrm{W} . \mathrm{W}$ et al [18] degradation of soil structure contributes to plastic thermal strain.

\section{Relationship of consolidation coefficient (Cv) and temperature $\left(\mathrm{T}^{\circ} \mathrm{C}\right)$}

The consolidation coefficient (Cv) of soft clay was also influenced by temperature variations. This condition aligned with results of the relationship of consolidation coefficient $(\mathrm{Cv})$ and temperature variations $(T)$, as shown in Figure 5. Under these circumstance, higher soil temperatures $(33 \%)$ obtained substantial coefficient value,

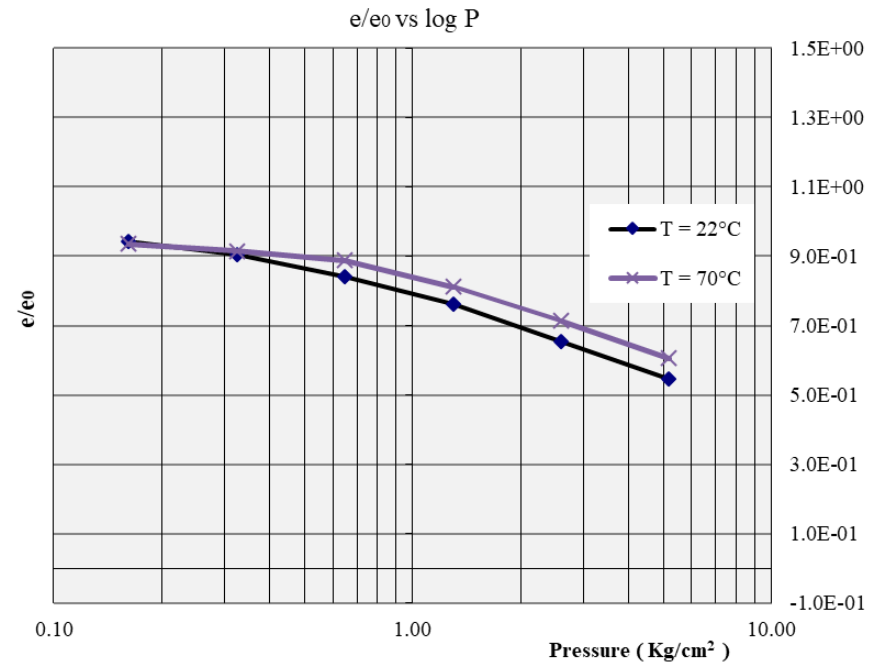

Figure 4: Relationship between eleo and pressure at temperature variations

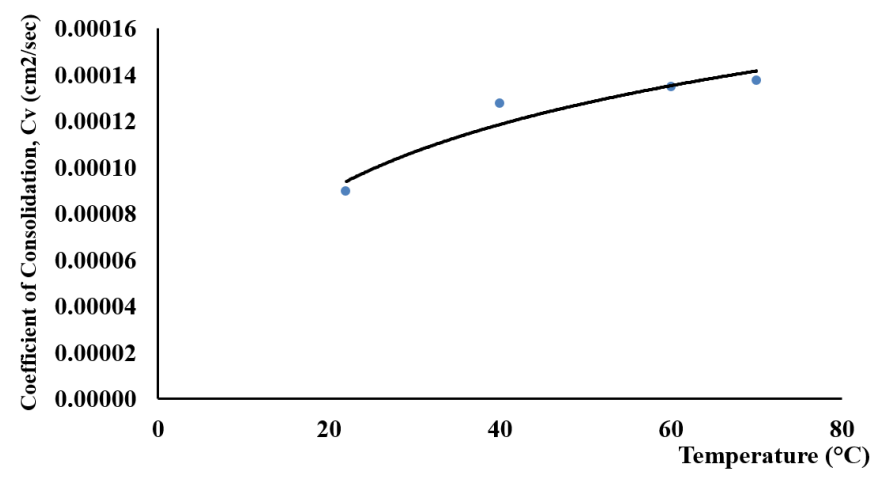

Figure 5: The relationship between the consolidation coefficient $(\mathrm{Cv})$ and temperature variations

and the subsequent modifications significantly influenced clay compressibility behavior.

The increase in consolidation coefficient of soft clay due to temperature was caused by changes in soil pores. Naga et al. [15] reported increasing consolidation coefficient (Cv) alongside heat was due to thermo-mechanical behavior in the soil in form of pore fluid bubbles, resulting to pore cavity expansion and water discharge. Consequently, Romero's et al [9] concluded the rising soil temperature potentially altered the clay fabric and pore water flow. Furthermore, Sridharan et al, [10] revealed the presence of heat in the soil demonstrated a significant effect on the physical forces between soil particles. Therefore, a possible change occurred in the pore water flow capacity, outflow water, and water concentration. $\mathrm{Ng}, \mathrm{C} . \mathrm{W} . \mathrm{W}$ et al [19] found that yield stress decreases with decreasing suction (wetting-induced softening). The observed thermal effects on wetting-induced softening are likely because with decreasing suction, the stabilizing interparticle normal force decreases more at a higher temperature.

\section{Relationship between swelling index (Cs) and temperature $\left(T^{\circ} \mathrm{C}\right)$}

Figure 5 shows the relationship between the swelling index (Cs) and temperature. However, Figure 6 revealed the extreme soil temperatures influence the soil compressibility through changes in the soil swelling index (Cs). This value also tends to increase by an average of $22 \%$, as temperature intensifies.

Burghignoli's et al [7] stated the creep behavior of soil bonds are affected by changes in soil temperature. Also, Gadzama's et al [11] reported the heat increase tends to trigger particle damage. Shahriar et al [20] show that an increase in the displacement rate leads to reduction in the equivalent plastic strain while an increase in the temperature leads to an increase in the equivalent plastic strain.

\section{Relationship between volume change coefficient (mv) and temperature $\left(T^{\circ} \mathrm{C}\right)$}

The results confirmed the volume change coefficient (mv) of soft clay was altered by soil temperature increase. Figure 7 shows enhanced heat effect tends to decrease the volume change coefficient (mv) by $3 \%$. A more sig- 


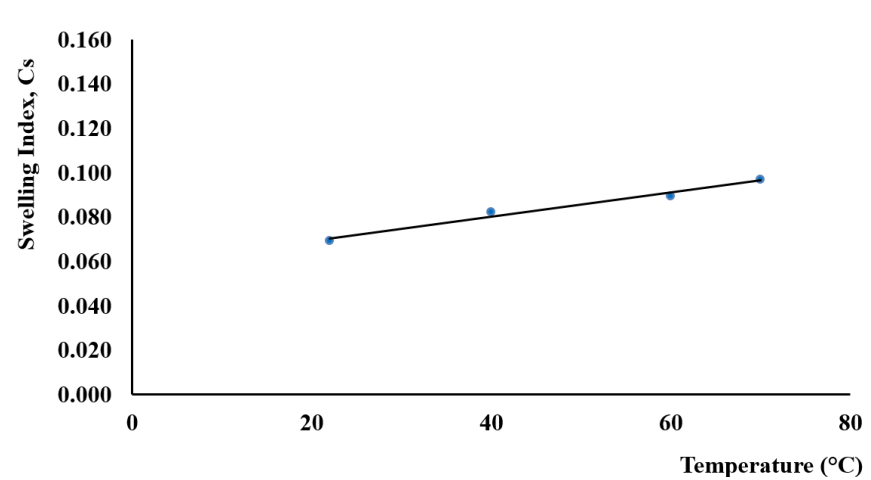

Figure 6: The relationship between swelling index (Cs) and temperature variations

nificant reduction occurred at temperature above $60^{\circ} \mathrm{C}$. This condition matched with the results on Kaolin clay by Mon's et al. [6], where the decline was probably due to a relationship with changes in soil stress.

Furthermore, Laloui [12] also stated the tendency of stress contraction phase to occur in the event of temperature surge, while Tsutsumi et al. [13] reported the formation of a new soil structure, under similar conditions. Zhu et al. [21] show that the extended model can reasonably describe the effect of bonding degradation on the stain-rate and temperature dependent behavior of soft structural clay under 1D condition. Ng, C.W.W., et al. [22] also stated the continuous contraction as the number of thermal cycles increased, these observed differences can likely be attributed to different distributions of clay particles in the soil specimens. Ng, C.W.W., et al. [23] found that a semi-empirical equation over-estimated the thermal expansion coefficient of normally consolidated (NC) lateritic clay by about 3 times. Vahedifard, et al. [24] has showen demonstrate the importance of considering temperature effects on the shear modulus of soils.

\section{Relationship between permeability coefficient (k) and temperature $\left(T^{\circ} \mathrm{C}\right)$}

Figure 8 shows the relationship between soil permeability coefficient (k) and temperature variations. Based on this figure, heat was believed to influence the permeability behavior of soft clay. Also, increasing temperature (up

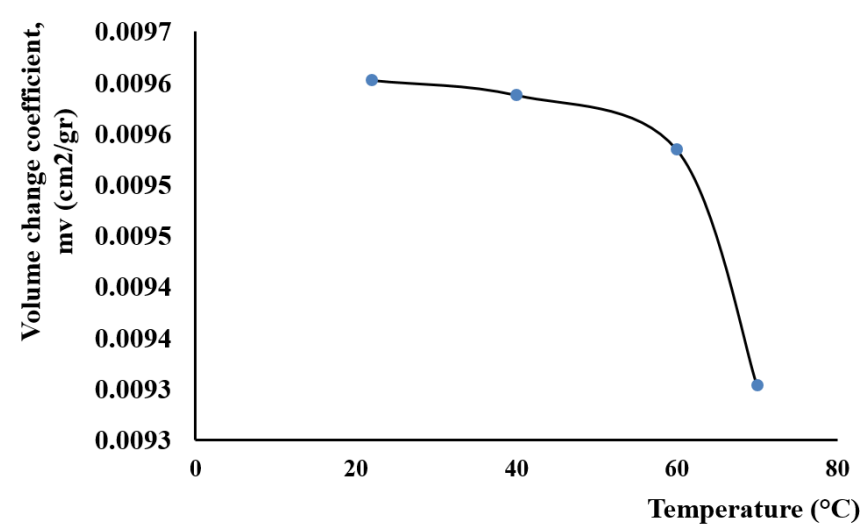

Figure 7: The Relationship between volume change coefficient ( $m v$ ) and temperature variation

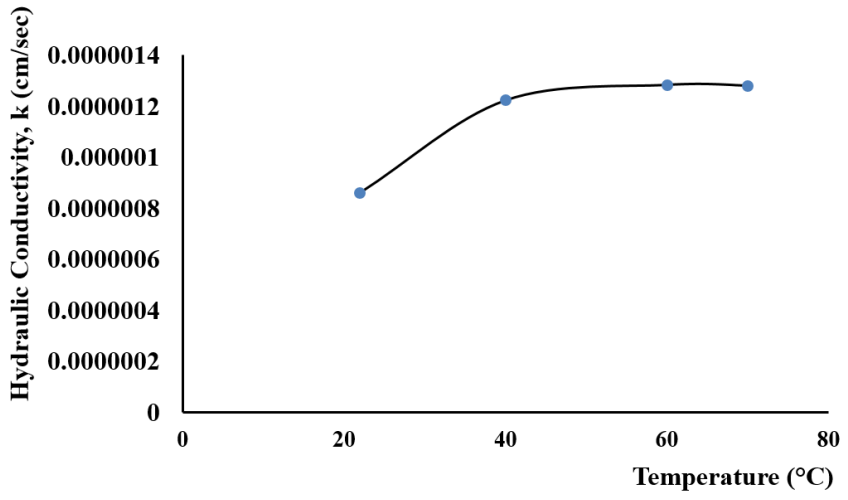

Figure 8: Relationship between soil permeability coefficient $(k)$ and temperature variations

to $40^{\circ} \mathrm{C}$ ) enhanced the soil permeability coefficient ( $\mathrm{k}$ ), by an average of $32 \%$. Subsequently, at values above $40^{\circ} \mathrm{C}$, the increment in coefficient $(\mathrm{k})$ becomes more gentle, compared to previous lesser estimates.

Towhata's et al [14] observed an increase in soil permeability due to temperature increase and viscosity decline. Furthermore, Romero's et al [9] in line with Gadzama's et al [11], observed soil heat have a potential to alter the clay soil structure (clay fabric) and pore water flow, due to the behavior of porosity redistribution, heat, and chemical interactions. Vahedifard, et al. [25] also stated nonisothermal applications involving geo-energy systems and soil-atmospheric interaction problems for soil water retention curve.

\section{CONCLUSION}

Based on the results and discussion, several conclusions were generated, as follows:

- Temperature variations significantly influenced soil compressibility, as both variables were known to increase proportionately.

- The increment in soil temperature enhanced soil compressibility parameters, termed soil compression index (Cc), consolidation coefficient (Cv), and the swelling index (Cs), by $3 \%, 33 \%$, and $22 \%$, respectively.

- Consolidation coefficient (Cv) of soft clay showed a greater improvement alongside increasing soil temperature, compared to other technical characteristics.

- High soil temperature possessed the ability to reduce fluctuations in soil volume, where the volume change coefficient $(\mathrm{mV})$ of soft clay tends to decline by $3 \%$, with rising temperature.

- The seepage properties of soft clay were boosted by $32 \%$, also with increasing temperature.

\section{ACKNOWLEDGEMENT}

The author is grateful to Lambung Mangkurat University through the Institute for Research and Community Service for the support and funding towards implementing this research for the 2020 Fiscal Year. 


\section{REFERENCES}

1. Holtz and Kovacs. (1981). An Introduction to Geotechnical Engineering, Transportation Research Board, Highway Capacity Manual 6thEdition, Prentice-Hall, Incorporated Route 9W Englewood Cliffs, NJ USA 07632

2. Davies, T. G. and Banerjee, P. K. (1980). Constitutive relationships for ocean sediments subjected to stress and temperature gradients. Report UKAEA/2/80, Department of Civil and Structural Engineering, University College, Cardiff.

3. Abuel Naga H.M., Bergado D.T., Soralump S., Rujivipat P. (2005). Thermal Consolidation Of Soft Bangkok Clay, LOWLAND TECHNOLOGY INTERNATIONAL, Vol.7 No.1, 13-21, Juni 2005, International Association Of Lowland Technology (IALT), ISSN 1344-9656

4. Slegel, D. L. and Davis, L. R. (1977). Transient heat and mass transfer in soils in the vicinity of heated porous pipes. Journal of Heat Transfer, 99: 541-621.

5. Moritz, L. (1995). Geotechnical properties of clay at elevated tempera- tures. In: Proceedings of the International Symposium on Compres- sion and Consolidation of Clayey Soils (IS-Hiroshima's 95), Hiroshima, vol. 1, pp. 267-272.

6. Mon Ei Ei, Hamamoto A. Kawamoto K., Komatsu T, and Moldrup P. (2013). Temperature Effect on Geotechnical Properties of Kaolin Clay: Simultaneous Measurement of Consolidation Characteristics, Shear Stiffness, and Permeability Using a Modified Oedometer, GSTF International Journal of Geological Sciences (JGS), Vol.1, No.1, April 2013.

7. Burghignoli A, Desideri A, Miliziano S. A. (2000). Laboratory study on the thermomechanical behaviour of clayey soils. Canadian Geotechnical Journal, 37 (4): 764-780.

8. Baldi, G., Hueckel, T., and Pellegrini, R. (1988). Thermal volume changes of the mineral-water system in low-porosity clay soils. Canadian Geotechnical Journal, 25: 807-825.

9. Romero E, Gens A, Lloret A. (2001). Temperature effects on the hydraulic behaviour of an unsaturated clay. Geotechnical \& Geological Engineering ;19(3e4):311e32.

10. Sridhan, A. and Venkatappa Rao, G. (1973). Mechanism controlling volume change of saturated clays and the role of the effective stress concept. Geotechnique. 23:359-382.
11. E. W. Gadzama., I. Nuhu., P. Yohanna. (2017). Influence of Temperature on the Engineering Properties of Selected Tropical Black Clays., Arab J Sci Eng (2017) 42:3829-3838 DOI 10.1007/s13369-0172485-3

12. Laloui, L. (2001). Thermo-mechanical behavior of soils. Revue Française de Génie Civil. 5(6): 809-843.

13. Tsutsumi, A., Tanaka, H. (2011). Compressive behavior during the transition of strain rate. Soils and Foundations 51 (5), 813-822, Science Direct, ELSEVIER

14. Towhata I, Kuntiwattanakul P, Seko I, Ohishi K. (1993). Volume change of clays induced by heating as observed in consolidation tests. Soils and Foundations ;33(4): 170e83.

15. Abdel-Hadi, O. N. and Mitchell, J. K. (1981). Coupled heat and water flows around buried cables. Journal of the Geotechnical Engineering Division, ASCE. 107(11): 1461-1487.

16. Donna, (2006). Perilaku Api dan Dampak Pembakaran terhadap Fauna Tanah pada Areal Penyiapan Lahan di Hutan Sekunder Haurbentes, Jasinga, Jawa Barat, Karya IImiah, Fakultas Kehutanan, Institut Pertanian Bogor (IPB)

17. C. C. Goodman F. Vahedifard. (2019). Micro-scale characterisation of clay at elevated temperatures. Géotechnique Letters 9:3, 225-230. DOI:10.1680/ jgele.19.00026.

18. C. Zhou, C. W. W. Ng. (2018). A new thermo-mechanical model for structured soil, Géotechnique Vol.68, pp.1109-1115, DOI:10.1680/jgeot.17.T.031

19. Ng, C.W.W. \& Cheng, Qing \& Zhou, Chao. (2018). Thermal effects on yielding and wetting-induced collapse of recompacted and intact loess. Canadian Geotechnical Journal. 55(8):1095-1103. DOI: 10.1139/cgj-2017-0332

20. Shahriar Shahrokhabadi, Toan Duc Cao Farshid, Vahedifard. (2020). Thermo $\square$ hydro $\square$ mechanical modeling of unsaturated soils using isogeometric analysis: Model development and application to strain localization simulation. International Journal for Numerical and Analytical Methods in Geomechanics 44:2,261-292. DOI:10.1002/nag.3015 
21. Zhu Q-Y, Jin Y-F, Shang X-Y, Chen T. (2019). A 1D model considering the combined effect of strainrate and temperature for soft soil. Geomechanics and Engineering 10;18(2):133-40. DOI:10.12989/ GAE.2019.18.2.133

22. Ng, C.W.W., Mu, Q.Y. and Zhou, C. (2019). Effects of specimen preparation method on the volume change of clay under cyclic thermal loads, Geotechnique, 69(2), 146-150. DOI:10.1680/jgeot.16.p.293.

23. Ng, C.W.W., Akinniyi, D.B. \& Zhou, C. (2021). Volume change behaviour of a saturated lateritic clay under thermal cycles. Bulletin of Engineering Geology and Environment 80, 653-661. https://doi. org/10.1007/s10064-020-01899-4
24. Farshid Vahedifard, Sannith Kumar Thota, Toan Duc Cao, Radhavi Abeysiridara Samarakoon, John S. McCartney. (2020). Temperature-Dependent Model for Small-Strain Shear Modulus of Unsaturated Soils, Journal of Geotechnical and Geoenvironmental Engineering, DOI:10.1061/(ASCE) GT.19435606.0002406, 146, 12, (04020136).

25. Vahedifard F, Cao TC, Thota SK, Ghazanfari E. (2018). Nonisothermal models for soil water retention curve. Journal of Geotechnical and Geoenvironmental Engineering, ASCE. ;144(9):04018061. DOI:10.1061/(ASCE)GT.1943-5606.0001939 